\title{
THE EUROPEAN VIEW ON GLOBAL ENTERPRISE COMPUTER APPLICATION IN PRODUCTION AND ENGINEERING
}

\author{
G. DOUMEINGTS
}

LAP/GRAI, University Bordeaux 1

351, Cours de la Libération, 33405 TALENCE France

Phone (33) 556846530 Fax (33) 556846644

E.mail : doum@lap.u-bordeaux

\author{
P. KOROHONEN, K. HUTTUNEN \\ Nokia Mobil Phone \\ Bo Box 86, 24101 SALO, Finland \\ Phone (358) 105051 Fax (358) 105055370 \\ E.mail : pertti.korhonen@nmp.nokia.com
}

These two papers will give an overview on the European situation in the domain of Computer Application in Production and Engineering.

We will present hereafter the summary of the Guy DOUMEINGTS paper. It is written with the support of well known European researchers : Prof. Jim BROWNE (CIMRU - National University of IRELAND - GALWAY and UMIST), Prof. Hans GRABOWSKI (RPK, University of Karlsruhe), Prof. Frank-Lothar KRAUSS (IPK Berlin), Dr Kei MERTINS (IPK - Berlin).

Today's manufacturing enterprises face a completely changed economic environment. The market has moved from a local market to a world wide global economy, the competitors become more and more agressif due to the emergence of open markets, reductions in trade barriers and improvement in transportation and communications links. Europeans manufacturing enterprises have adopted the same strategy than the enterprises belonging to the other continents : improvement of the competitiveness in all functions, reactivity to the market change by integrating all functions, adopting a Business Processes Structures and finally working more closely with their suppliers and customers by building Extended Enterprises in order to improve the whole Value Chain.

We will use the model of Manufacturing Business proposed by [Browne 96] to structure our presentation : 


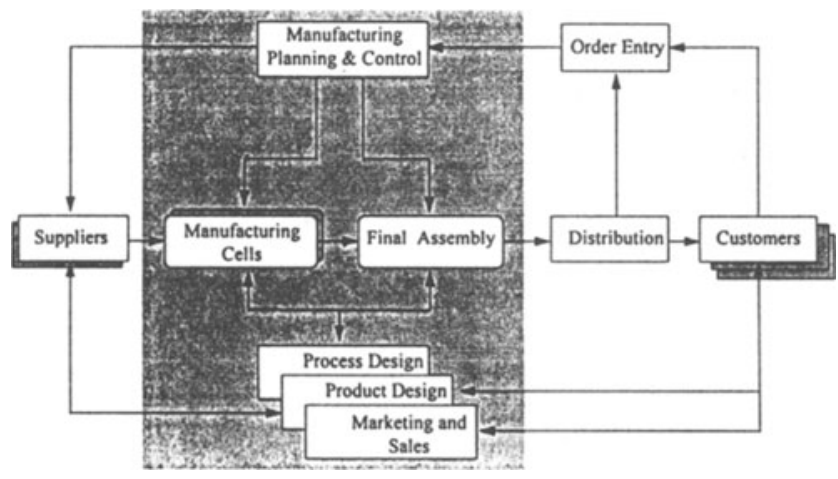

Integration in Manufacturing

The first paragraph describes the evolution of the concepts of the Extented Enterprise which can concern all the parts of the model.

The second part presents the use of EDI (Electronic Data Interchange) in the Product and Process Design : CDI (CAD/CAM Data Interchange). CDI is developed today in Europe through European Consortium (as AIRBUS Industry). Its development is facilitated by the development of product data modelling (PDM) and the standardization through STEP.

The third part describes the evolution of Production Management from MRP II to ERP (Enterprise Ressources Planning), evolving also from MTS (Make to Stock) to MTO (Make to Order). The Supply Chain Management and the Demand Chain Management are described in details by the joint paper.

The fourth part will discuss the need of technics in order to elaborate the various model of the Integrated Manufacturing System. The Computer Aided Technics, today available, cannot be used efficiently if the company is not able to design, at a conceptual level, the optimised model in terms of Business Processes. Enterprise Modelling Technics will be more and more used in order to facilitate the implementation of New Technology.

The European View on Global Enterprise in the domain of Computer Application in Production and Engineering is certainly very closed than the views in other continents due to the globalization of the economy. Anyway through the various Research and Development supported by European Commission (ESPRIT, BRITE/EURAM,...) and also by the European States (EUREKA) it exists a European way to introduce the Advanced Technology in the Enterprises.

\section{REFERENCES}

Browne, J., Jagdev, H.S. (1996) The Extended Enterprise : a Context for Product Development and Production. Internal Publication (CIMRU - National University of IRELAND - GALWAY and UMIST).

Krause, F.L., Doblies M. (1997) A Communication Environment for Global Automotive Engineering. Proceeding International Symposium on Global Engineering Networking - Antwerpen 1997 - Eds J. GAUSEMEIER.

Krause, F.L., Doblies M. (1995) Product Development using IBC. Proceeding of the First International SMC Workshop Integrated Broadband Communications and Collaborative Work in the Automotive Industry (CWIBC) - May 10-11/1995 - University of Trento - Italy.

Grabowski, H., Pocsai Z.S. (1997) Electronic Market Place : Beyond the Vision.

Proceeding of the International Symposium on Global Engineering Networking - April 97 - Antwerpen. 
Kurz, A., Pusch R. (1997) BKKN : Berliner Kreis Kompetenz Netzwerk : Know How Transfer from Campus to Industry via Internet.

Proceeding of the International Symposium on Global Engineering Networking - April 97 - Antwerpen.

Faux, J., Kestelet, P., Langtoz, G., Pocsai, Zs., Radeke, E., Stewing, F.J. (1997) Exploitation of Product Data Technology by the Global Engineering Networking Initiative.

Proceeding of the European Conference Product Data Technology Days - April 97 - Sophia Antipolis - France.

Elovaino, K., Kunz J. (1997) DOCSTEP : Technical Documentation Creation and Management using STEP. SGML Europe 97 Conference - May 97 - Barcelona - Spain.

Grabowski, H., Rude, S., Pocsai, Zs. (1997) Ontology Technology : the KEY for Intelligent migration and retrieval of Information in Engineering Networks.

International Conference on Engineering Design ICED 97 - August 97 - Tampere - Finland.

Mertins, K., Edeler, H., Jochem, R., Hofmann J. (1995) Object-Oriented Modelling and Analysis of Business Processes in Integrated Manufacturing Systems Engineering - Chapman \& Hall.

Doumeingts, G., Ducq, Y.(1996) Production Management : which Future.

Advances in Production Management Systems Conference - Kyoto - Japan.

Doumeingts, G., Vallespir, B., Marcotte, F. (1995) A Proposal for an Integrated Model of Manufacturing System : Application to the re-engineering of an Assembly Shop.

Control Engineering, Special Section on Models for Management and Control, Vol. $3 n^{\circ} \mathrm{l}$, Oxford, Pergamon Press Ltd, pp 59-67.

Doumeingts, G., Vallespir, B., Chen, D. (1995) Methodologies for Designing CIM systems.

A survey - Computers in Industry, Special Issue on CIM in the Extended Enterprise, Vol. $25 n^{\circ} 3$, Amsterdam, Elsevier, pp 263-280.

Doumeingts, G., Vallespir (1995) A Methodology Supporting Design and Implementation of CIM Systems including Economic Evaluation.

in Book "Optimization Models and Concepts in Production Management" Ed. P. Brandimarte \& A. Villa Gordon and Breach Science Publishers, pp. 307-331. 